
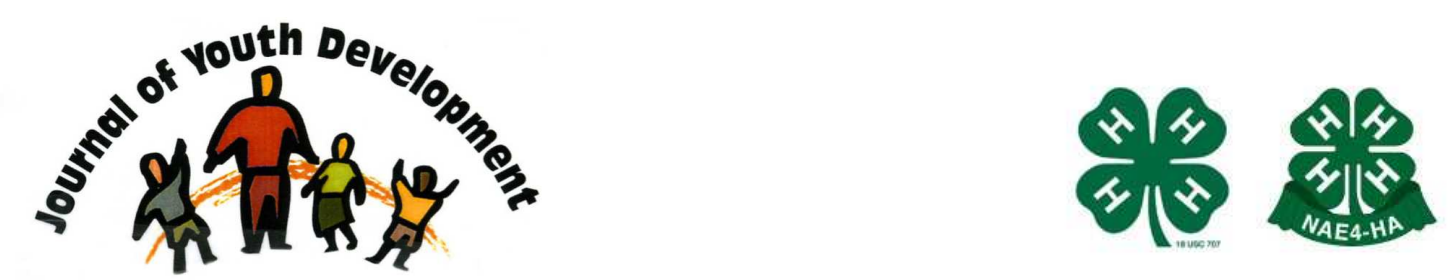

Bridging Research \& Practice

\title{
Implementing a Work-Based Learning Approach to 4-H Camp Counseling
}

\author{
Theresa M. Ferrari \\ 4-H Youth Development \\ The Ohio State University \\ Columbus, $\mathrm{OH}$ \\ ferrari.8@osu.edu
}

Nate Arnett

4-H Youth Development

The Ohio State University

Dayton, $\mathrm{OH}$

arnett.67@osu.edu 


\title{
JOURNAL OF YOUTH DEVELOPMENT \\ bridging research and practice

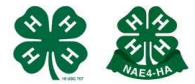

\section{Implementing a Work-Based Learning Approach to 4-H Camp Counseling}

Theresa M. Ferrari and Nate Arnett

\begin{abstract}
Although camping has been a successful 4-H delivery method, we believed a more intentional approach that viewed camp counseling as a job would allow teen camp counselors to connect skills they were learning with those needed for workforce success. Eighteen Ohio counties participated in a pilot project to test the implementation of this work-based learning approach. 4-H youth development professionals added specific workforce-related topics and made minor changes in their camp counselor training. In addition, they used a performance appraisal process consisting of teens' self-assessment and supervisor assessment. Focus groups were conducted to gain implementation data. Although there were some challenges, this approach took relatively little additional effort, and there were benefits for both counselors and professionals. This intentional approach could be applied to other youth programs.
\end{abstract}

\section{Introduction}

Camping is one of several delivery methods in the 4-H program. Ohio uses a county-based model for its camping program, where each county runs a camp staffed with teen camp counselors who are selected through an application and interview process and trained by the county 4-H professional. In contrast to states that use paid staff, the Ohio 4-H camp counselor role is a volunteer position and is for one camp session rather than the entire season. These teen counselors assume significant responsibility for planning and conducting a four to five-day program for younger campers.

Previous research has documented that 4-H camp counseling provides a positive developmental context conducive to developing identity (Digby \& Ferrari, 2007; Ferrari \& McNeely, 2007; Garst, Franz, Baughman, Smith, \& Peters, 2009). In addition, camp counselors develop skills such as leadership, teamwork, and initiative (Brandt \& Arnold, 2006; Carter, 2006; Digby \& 
Ferrari, 2007; Duda, 2009; Ferrari \& McNeely, 2007; Forsythe, Matysik, \& Nelson, 2004; Garst \& Johnson, 2005). Many describe it as the highlight of their 4- $\mathrm{H}$ experience.

It turns out that the skills gained by camp counselors are also those valued by employers (Casner-Lotto, 2006; Levy \& Murnane, 2006), and from our past research we knew that counselors applied the skills they learned once they were in college or in the workforce (Digby \& Ferrari, 2007). However, we believed a more intentional approach would allow counselors to make these connections sooner, thereby adding value to the program (Cochran \& Ferrari, 2009). Thus we proposed to view camp counseling as an opportunity for work-based learning. Over two years, a total of 18 counties participated in a pilot project to explore this approach. We gathered 4-H professionals' feedback regarding program implementation in focus group interviews held in the month following completion of the camping season. We discuss the workbased learning approach and share the results of the program implementation in this article.

\section{Workforce Skills and Work-Based Learning}

Work-based learning enables youth to have real work experiences that are coupled with supports that help them to learn about themselves and to understand the expectations of the world of work (Cochran \& Ferrari, 2009; Ferrari, Arnett, \& Cochran, 2008). In this approach, youth are learning workplace skills through work in a concrete way rather than learning about work in an abstract sense or learning about a specific career path. It takes into account the developmental needs of young people as they learn by doing in a work setting, which is congruent with the theory of developmental intentionality (Walker, 2006; Walker, Marczak, Blyth, \& Borden, 2005).

Although there will always be specific skills needed that are based on specific work tasks (i.e., technical competencies; Hamilton \& Hamilton, 2004), work-based learning should focus on skills that are necessary for success in any job. We have categorized these workforce skills into six broad areas:

- thinking skills,

- communication skills,

- teamwork and leadership,

- lifelong learning and self-direction,

- technology adoption and application, and

- professionalism (see Table 1)

These are the skills that transfer to a variety of work settings, because they have to do with one's approach to work, interactions with others, and the application of skills to work tasks and roles. For example, whereas leading a group of 10 nine-year-olds in a get-acquainted activity is specific to the job of a camp counselor, leadership is a skill needed throughout the workforce. 
Table 1

Skills for Success in the Knowledge Economy

\begin{tabular}{|l|l|}
\hline \multicolumn{1}{|c|}{ Skill Area } & \multicolumn{1}{c|}{ Description } \\
\hline Thinking Skills & Critical thinking, problem solving, decision making, creativity, and innovation \\
\hline $\begin{array}{l}\text { Communication } \\
\text { Skills }\end{array}$ & $\begin{array}{l}\text { The ability to communicate effectively using a variety of tools and methods available } \\
\text { in today's environment; includes verbal and written communication }\end{array}$ \\
\hline $\begin{array}{l}\text { Teamwork \& } \\
\text { Leadership }\end{array}$ & $\begin{array}{l}\text { The interpersonal skills necessary to work effectively in a team and to provide } \\
\text { leadership through collaboration, motivation, and leveraging the strengths of others }\end{array}$ \\
\hline $\begin{array}{l}\text { Lifelong Learning } \\
\text { and Self-Direction }\end{array}$ & $\begin{array}{l}\text { Continually improving one's capabilities by taking responsibility to set goals, improve } \\
\text { skills, and show initiative }\end{array}$ \\
\hline $\begin{array}{l}\text { Technology } \\
\text { Adoption \& } \\
\text { Application }\end{array}$ & $\begin{array}{l}\text { A firm foundation of technology skills including concepts and operations, selecting } \\
\text { appropriate tools, and solving problems with appropriate technology }\end{array}$ \\
\hline Professionalism & $\begin{array}{l}\text { Demonstrate personal accountability and effective work habits: punctuality, working } \\
\text { productively with others, and time and workload management }\end{array}$ \\
\hline Source: Cochran \& Ferrari (2009), adapted from Cochran \& Lekies (2008) \\
\hline
\end{tabular}

Youth development professionals tend to refer to the skills in Table 1 as life skills. We see the value of using the terminology workforce skills or $21^{\text {st }}$ century skills because it is language that reframes these skills in a way that will resonate with stakeholders (Cochran \& Ferrari, 2009; Cochran, Catchpole, Arnett, \& Ferrari, 2010). A focus on these skills is important for several reasons. For one, they are skills that are needed for success beyond the workplace-for success at school, in civic activities in the communities, in families, and for the healthy transition from adolescence to adulthood (Hamilton \& Hamilton, 2004; Lippman, Atienza, Rivers, \& Keith, 2008). However, employers indicate that many new entrants to the workforce lack these skills (Business \& Higher Education Forum, 1997; Casner-Lotto, 2006; Partnership for $21^{\text {st }}$ Century Skills, 2002). Furthermore, once they enter the workforce, young people likely will experience many job changes during their first 10 years (Veum \& Weiss, 1993). Job changes continue even as workers grow older (Bureau of Labor Statistics, 2010). Such skills will serve them well in these different work settings.

A common feature of many of these workforce skills is that they involve demonstrating mastery, which is not likely to develop without practice. For example, simply reading about the steps for solving a problem will not ensure that an individual can actually solve a problem when presented with one in a real-life setting. Thus, there is a focus on learning in a work-based learning approach. Because learning is a missing ingredient in typical adolescent employment (Greenberger, Steinberg, \& Ruggerio, 1982), a work-based learning approach embedded within a youth development program provides a safe setting for practicing and refining skills under the guidance and support of adult mentors.

Youth programs are thought to be a setting that is ideally suited to addressing adolescents' real-world skill development (Larson \& Angus, in press; Schwarz \& Stolow, 2006). To meet young people's need for job experience and workplace readiness, youth development organizations should consider how they can incorporate these aspects into their program (Lippman et al., 2008). As well, part of the learning process is for young people to learn what skills are necessary for success, to be aware that they have developed them, and to know how to communicate their skills to potential employers. A work-based learning approach within the context of a youth development program can address these needs. 


\section{Work-Based Learning Goes to Camp}

Although the outcomes of educational programs are certainly important, it is just as important to understand how these outcomes come to be, that is, the theory behind the program (Garst, 2010). To better understand implementation, we discuss each component of the camp experience and describe how we integrated the work-based learning approach.

\section{Components of a Work-Based Learning Approach to Camp Counseling}

As depicted in Figure 1, there were five components to implementing a work-based learning approach in the 4-H camp counselor program. These components are described briefly below.

Figure 1

Components of the 4-H Camp Counselor Work-Based Learning Project

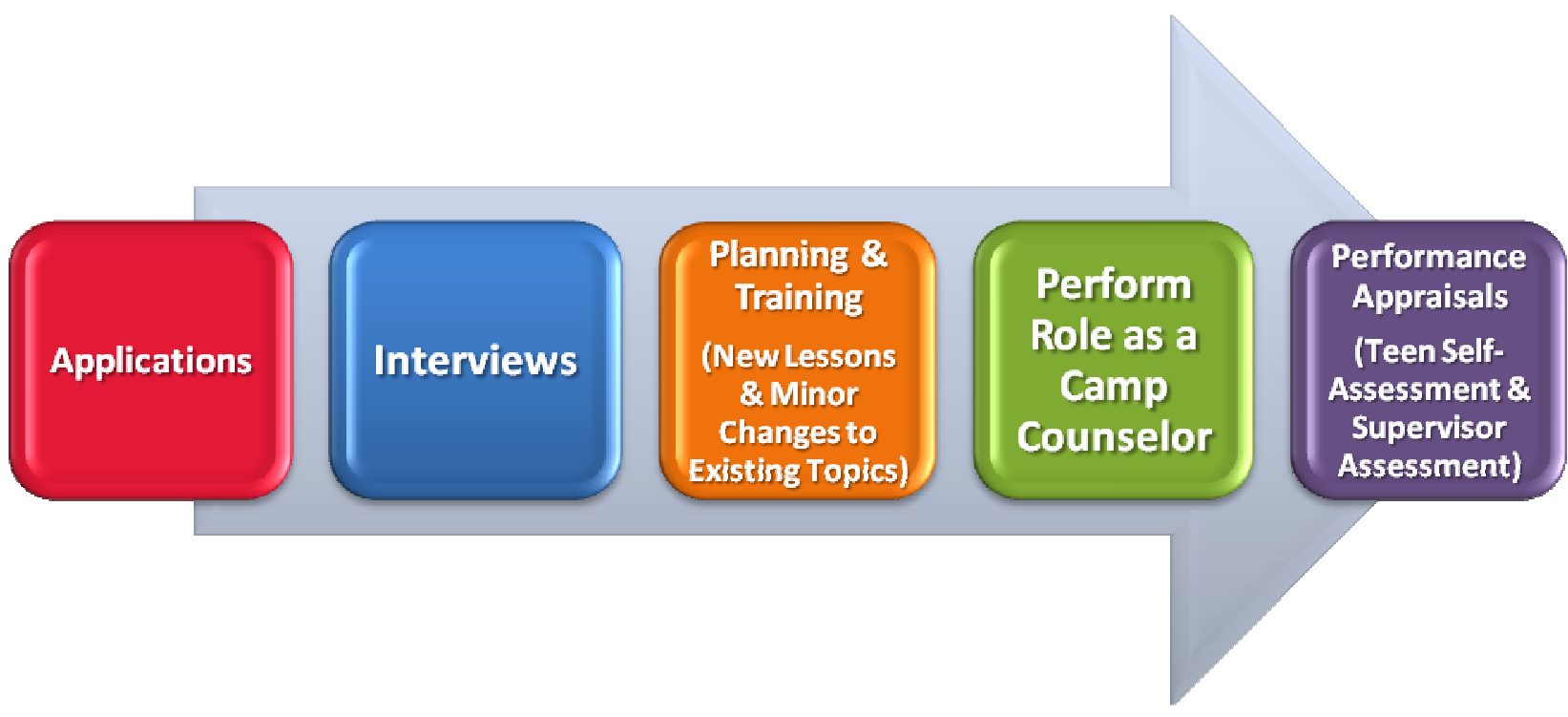

Applications and interviews. Typically, counselor recruitment and selection occurs in November and December. 4-H professionals in Ohio have used applications and interviews for many years, so these components were already in place. They serve the practical purpose of selecting counselors, but they are also used intentionally to prepare teens for future situations such as college applications and job interviews. However, we found that using the work-based learning approach encouraged some counties to strengthen their process, such as using a more formal application process or by expanding their interview questions.

Planning and training. Training sessions are generally conducted between January and May. Training follows Ohio 4-H and American Camp Association guidelines and includes topics such as philosophy of camping, ages and stages of development, behavior management, and dealing with homesickness. Some training is conducted in multi-county clusters (e.g., a weekend retreat at the camp site). The counselors are also involved in planning the camp program (e.g., deciding on a theme, creating campfire programs, planning all-camp activities). Counselors are involved in leadership roles on committees and most devote additional time to preparation (Ferrari, Arnett, \& Bateson, 2010). 
We did not prescribe a specific curriculum, but rather asked 4-H professionals to make some adaptations to their training to introduce at least two lessons containing work-based learning concepts and $21^{\text {st }}$ century skills terminology. They did this in two ways:

1. Adding new lessons: There were two areas where new training topics were introduced (a) comparing camp counseling to a job and (b) resume writing.

2. Adjusting existing lessons by reinforcing the workforce skills inherent in camp counseling: They drew out these connections when they discussed activities in training sessions. For example, a lesson on communication reinforced how this skill was important in the workforce. The key was that this application to camp counseling, and to the world of work more generally, was an intentional process.

In Table 2 we provide an expanded description of these adaptations by using quotes from the 4-H professionals.

\section{Table 2}

\section{Camp Counselor Training Activity Descriptions}

"Just Doing My Job" - Comparing Camp Counseling to a Job

In this activity, counselors brainstormed two lists: one with the skills needed to be a good employee and another with those needed to be a good camp counselor. When the lists were compared, they realized the similarities.

"We did a lesson about... what makes a good employee....how that is similar to being a camp counselor. We just really led the counselors through a process of making that relationship between a lot of the characteristics and traits and values of a good employee and having them list those, and then we talked about those and why they were important as a good employee and how those related to being a camp counselor."

Resume Writing

Several different approaches were used, but essentially counselors developed resumes, specifically learning about how to describe their camp counseling experience and the skills they gained.

"We made them actually walk through what they'd done... what kind of skills had they developed and how can they write that down, and we used a list of like common verbs, action words, that they can use in their resume, like 'developed leadership.' And they started picking up on those buzz words by the end of the weekend and would say instead of 'I went [to camp] and I was a camp counselor,' it was 'I did youth development. "'"

\section{Reinforcing Workforce Skills}

Reinforcement was not an activity as such, but happened continually throughout the training. Because the 4-H professionals leading the training were intentional in their focus on workforce skills, they could take advantage of teachable moments throughout.

"Throughout our training, we focused a lot on being prepared, being there on time, your presentation of yourself, being ready to go when you needed to, just as if you would in a regular job.... We didn't necessarily take a specific lesson and say 'this is a workforce prep lesson,' we incorporated everything throughout our training."

"For each activity we always talked at the end about how it applied to camp...and how it applies to things outside of just camp, how what they learned they could use on the job or in school."

Camp. Camps are usually held in June and July. Counselors work as part of a team to create a successful camp, working closely with other counselors to share responsibility for a group of 
younger campers. It is a $24 / 7$ responsibility, as they live together in a cabin, facilitate group interactions, and supervise activities of daily living such as cabin clean up and dining hall duties. The majority of counselors (up to $80 \%$ ) teach educational sessions during the camp program (Ferrari , Arnett, \& Bateson, 2010). They may teach a wide variety of topics such as songs, teambuilding activities, nature, or crafts.

Performance appraisal. The performance appraisal consisted of the teen counselors' selfassessment and assessment by the $4-\mathrm{H}$ professional. The assessment included 24 workforce skills grouped into five categories (Table 3 ) and was completed at the conclusion of camp. There were two ratings given: a retrospective rating of skill level as perceived at the start of the process and another rating post-camp. We used this method because it reduces response-shift bias, that is, the tendency to rate oneself high at the beginning of an educational program (e.g., Marshall, Higginbotham, Harris, \& Lee, 2007; Rockwell \& Kohn, 1989), and also based on its success with other workforce preparation programs (Ferrari et al., 2008). The ratings were given on a five-point scale: (1) needs significant improvement, (2) needs some improvement, (3) demonstrates basic skill level, (4) sometimes excels, and (5) consistently excels.

Table 3

Workforce Skills Performance Appraisal

\begin{tabular}{|c|c|}
\hline Category & Items (a) \\
\hline \multirow[t]{3}{*}{ Thinking Skills } & 1. I make good decisions. \\
\hline & 2. I think through difficulties and solve problems. \\
\hline & 3. I am creative. \\
\hline \multirow{4}{*}{$\begin{array}{l}\text { Communication } \\
\text { Skills }\end{array}$} & 4. I express thoughts clearly to others. \\
\hline & 5. I am comfortable speaking in front of a group. \\
\hline & 6. I am a good listener. \\
\hline & 7. I am a good writer. \\
\hline \multirow{5}{*}{$\begin{array}{l}\text { Teamwork and } \\
\text { Leadership } \\
\text { Skills }\end{array}$} & 8. I work well with others to achieve a goal or complete a project. \\
\hline & $\begin{array}{l}\text { 9. I work well with others to resolve disagreements in a way that is fair } \\
\text { and respectful. }\end{array}$ \\
\hline & 10. I lead others to achieve a goal. \\
\hline & 11. I can organize people around an idea, problem, or cause. \\
\hline & 12. I encourage and support others. \\
\hline \multirow[t]{4}{*}{ Initiative } & 13. I take the initiative for getting things done. \\
\hline & 14. I set goals and work hard to meet them. \\
\hline & 15. I ask for help when needed. \\
\hline & $\begin{array}{l}\text { 16. I have the motivation to complete work or project tasks without } \\
\text { needing reminders. }\end{array}$ \\
\hline \multirow[t]{8}{*}{ Professionalism } & 17. I manage time well. \\
\hline & 18. I have good work habits (being punctual, honest, and responsible). \\
\hline & 19. I have a positive attitude about work. \\
\hline & 20. I dress appropriately for the job. \\
\hline & $\begin{array}{l}\text { 21. I work well with people from diverse backgrounds (different ages, } \\
\text { races, genders, religions, cultures, lifestyles, and viewpoints). }\end{array}$ \\
\hline & 22. I meet scheduled deadlines. \\
\hline & 23. I offer suggestions for improvements for the program. \\
\hline & 24. I am respectful of others. \\
\hline
\end{tabular}


(a) Items presented here are the statements on the teen self-assessment. The same 24 items are used for the supervisor's assessment; the wording of the statements is adjusted slightly (e.g., "The teen makes good decisions").

Response scale: (1) needs significant improvement, (2) needs some improvement, (3) demonstrates basic understanding, (4) sometimes excels, and (5) consistently excels. There is also the option to select "not applicable" or "not observed." After each of the five sections there is a space for comments. Adapted from Ferrari, Arnett, \& Cochran, 2008

4-H professionals scheduled a meeting with each camp counselor to occur within a few weeks following the camp program's conclusion to review the assessments and to provide performance feedback. The estimated time of completion for the counselor assessments was 15 minutes each, with additional time for the face-to-face meeting. They also used this time to get feedback from the counselors on the camp program.

\section{Adult-Youth Relationships: They Do Matter}

Relationships with adult leaders are recognized as a key feature that contributes to positive youth development (Eccles \& Gootman, 2002; Grossman \& Bulle, 2006; Rhodes, 2004). The 4-H youth development professionals who facilitate the camp counseling program support counselors' skill development by allowing them to assume major responsibility for planning and implementing the camp program. However, adult leaders also must exercise judgment about the amount and type of support needed, shifting as the situation demands (Larson, Hansen, \& Walker, 2005; Larson \& Angus, in press). In practice, it is a challenge to balance the competing demands inherent in the process of facilitating youth's development while caught up in the "daily tumble of events" (Larson, Rickman, Gibbons, \& Walker, 2009, p. 71).

Counselors' comments illustrate that important elements of these relationships were present: the adults who work with camp counselors provide both emotional and instrumental support that helps them (the teens), and the program, to be successful.

"They are fun to work with and easy to be around."

"Working with our adults was an amazing experience because they had camp experience, so they teach us the most important things we need to know."

"The adults in the program listened to our ideas and gave suggestions on how to improve our ideas and how to make the best choices. They really cared and tried to make it the best camp possible."

"They make it clear that you can go to them for anything. They won't think any less of you if you ask them for anything."

"The adults made the job of being a counselor as a 'real job. "'

"She assured me of the good job I was doing and that made me work harder."

These comments illustrate that we need to understand not just what is done, but how it is done, to get a complete picture of program implementation. Relationships developed between youth and adults are thought to be one of the mechanism by which youth become engagedbecause these connections allow them to "soak up' the lessons and messages imparted" (Jones \& Deutsch, 2010, p. 22)-and, in turn, outcomes are achieved. Therefore, neglecting the importance of adult relationships as part of implementation can alter a program's success. 


\section{Benefits and Challenges of the Work-Based Learning Approach}

The 4-H professionals who participated in the camp program provided feedback about using this work-based approach. Two major themes emerged from these discussions. First, 4-H professionals found that it was relatively easy to embed workforce topics in their counselor training, and thus it did not require much change to implement. Many noted that they were already including many aspects of workforce skills, but this approach emphasized them and made it much more intentional. The other aspect that generated the most discussion was the performance appraisals, which were a new addition. The performance appraisals provided documentation of counselors' performance, increased interaction with counselors, and provided helpful feedback on the camp program. Because of this, the participants said the performance appraisals were a "must do" aspect of the approach. The benefits and challenges are summarized below; Table 4 expands on the benefits.

\section{Benefits for Camp Counselors}

- Counselors gained an awareness of the skills they were developing.

- Counselors appeared to take their job as a counselor more seriously.

- Counselors' performance improved.

- Counselors realized how skills they developed would help them now and in the future.

Overall, counselors gained insight into the work of work in general and were aware of gaining significant leadership skills and responsibility. They also gained self-awareness and insight into career decisions. Specific results regarding these insights and skills are described elsewhere in more detail (Ferrari et al., 2010).

\section{Benefits for 4-H Professionals}

- It was relatively easy to do and did not require drastic changes to implement.

- It helped them to deal with some past challenges (e.g., counselors taking the responsibility seriously, lack of attendance at training sessions) by giving workforce skills development and job performance as a frame of reference.

- It increased interaction with counselors and provided helpful feedback on the camp program.

- It provided documentation about a counselor's performance that was useful for making decisions about participation in subsequent years. In a few cases, this meant providing justification in the event that a counselor was not asked back.

- A successful camp was not only one that was positive for campers, but was one that achieved youth development outcomes for counselors as well. 


\section{Table 4}

Benefits of a Work-Based Learning Approach as Perceived by 4-H Professionals

\begin{tabular}{|c|c|}
\hline Benefit & Representative Comments \\
\hline $\begin{array}{l}\text { Improved Counselor } \\
\text { Performance }\end{array}$ & $\begin{array}{l}\text { "We didn't run into nearly the trouble this year with them running late or being } \\
\text { in the wrong place at the wrong time, or not being where they needed to be. } \\
\text { They took that [responsibility] pretty seriously, which was a big improvement } \\
\text { over the last few years." } \\
\text { "There seemed to be more respect for the adult volunteers... there seemed to } \\
\text { be a lot more teamwork..." } \\
\text { "Older teens wanted to step up and lead because they saw the opportunity as } \\
\text { skill development." }\end{array}$ \\
\hline $\begin{array}{l}\text { Enhanced } \\
\text { Counselors' } \\
\text { Awareness of Their } \\
\text { Skills and } \\
\text { Workforce } \\
\text { Connections }\end{array}$ & $\begin{array}{l}\text { "I feel the teen self-assessment benefitted our camp counselors to see what } \\
\text { they are good at, what they need to work at, and ways of getting to the point } \\
\text { they would like to be." } \\
\text { "They saw this as a move towards the world of work, as more of a responsibility } \\
\text { versus 'I'm just here to have fun,' and that's been a big change over the past } \\
\text { couple of years with our camp...they're there to be a leader." }\end{array}$ \\
\hline $\begin{array}{l}\text { Relative Ease of } \\
\text { Implementation }\end{array}$ & $\begin{array}{l}\text { "I realized there were a lot of little things that didn't require a lot of extra time } \\
\text { or effort. Just slight changes that would really change the experience for the } \\
\text { camp counselors, and really make it a workforce development program in } \\
\text { addition to training them to go to camp. So I think it is a great approach and I'd } \\
\text { recommend anybody implement it." }\end{array}$ \\
\hline $\begin{array}{l}\text { Increased } \\
\text { Interaction with } \\
\text { Counselors }\end{array}$ & $\begin{array}{l}\text { "Probably the biggest thing gained was the one-on-one interaction with the exit } \\
\text { interviews. We've never done those before and I would not stop doing the exit } \\
\text { interviews." }\end{array}$ \\
\hline $\begin{array}{l}\text { Reaching Youth } \\
\text { Development } \\
\text { Outcomes }\end{array}$ & $\begin{array}{l}\text { "Before, doing a good camp was the end product. Now, the end product is a } \\
\text { good camp and preparing teens for life." } \\
\text { "I found this approach was helpful in relating to parents and other educators } \\
\text { the value of the camp experience and why it should be a priority activity." }\end{array}$ \\
\hline $\begin{array}{l}\text { Overall Success of } \\
\text { Camp }\end{array}$ & $\begin{array}{l}\text { "We had one of the best camps we've ever had. This year we added the } \\
\text { workforce prep piece and that's the only thing I can attribute it to." }\end{array}$ \\
\hline
\end{tabular}

\section{Challenges}

Participants noted several challenges regarding implementation. These challenges were more about the process itself rather than with the concept of work-based learning.

\section{- Time Constraints}

- Performance appraisals were time consuming.

- Time constraints on the part of both counselors and 4-H professionals made scheduling performance appraisals difficult.

- Individual interviews were difficult if a county had a large number of counselors.

\section{- Dealing with Change}

- One can expect to experience some resistance when a new approach is introduced. 
Some solutions to these time challenges were scheduling phone interviews and arranging for small groups to come together for part of the interview, followed by a shorter individual meeting. Although the means differed, ultimately the intent of providing performance feedback was accomplished.

\section{Conclusions and Implications}

Based on the experiences of 4-H professionals who implemented this approach, we draw the following conclusions:

- With relatively little effort, workforce skills can be successfully incorporated into camp counselor training.

- Those who consider adopting this approach should be aware that it will take an investment of time to complete performance appraisals.

- Using a performance appraisal process is mutually beneficial for counselors and 4-H professionals.

- Using a work-based learning approach adds value to the camp counselor program in two ways:

- Counselors viewing camp counseling like a job.

- Counselors making connections between what they are learning and the world of work.

- Better performance by counselors leads to a higher quality, safer camp.

- Development of positive relationships between adult leaders and teen camp counselors likely influences the program's successful implementation.

Camping is a tried and true method of engaging young people; however, many see it as just fun and games around the campfire and not as a means for developing counselors' workforce skills. Stakeholders are interested in whether youth programs produce a return on investment; a "value added" approach can help make these connections (Cochran \& Ferrari, 2009, p. 19; see also Cochran et al., 2010; Lamm \& Harder, 2009). As programs are pushed to document impact, demonstrating that workforce skills are the outcomes of youth programs is particularly timely. Many programs aim to prepare youth as contributing members of society now as well as for a successful transition to adulthood and could benefit from considering the intentional approach and work-based learning concepts presented here.

\section{Acknowledgements:}

Portions of the article were presented at the 2010 National Association of Extension 4-H Agents annual conference in Phoenix, AZ.

Funding for this project was provided by the Erie and Orlyss Sauder endowment of the Ohio 4-H Foundation.

We thank the Ohio 4-H professionals who participated in this project: Nadine Fogt, Connie Goble, Heather Gottke, Tonya Horvath, Mark Light, Mary Longo, Vicky Oboy, Jessica Rockey, Susan Russell, Gwen Soule, Jill Stechschulte, Kathy Tackett, Cassie Turner, Travis West, Tracy Winters, Janine Yeske, Bruce Zimmer, and Raci Zimpfer, and the camp counselors in their respective counties. 


\section{References}

Brandt, J., \& Arnold, M. (2006). Looking back, the impact of the 4-H camp counselor experience on youth development: A survey of counselor alumni. Journal of Extension, 44(6), Article 6RIB1. Retrieved from: http://www.joe.org/joe/2006december/rb1.php

Bureau of Labor Statistics. (2010, September 10). Number of jobs held, labor market activity, and earnings growth among the youngest baby boomers: Results from a longitudinal survey [news release]. Retrieved from: http://www.bls.gov/news.release/nlsoy.nr0.htm

Business-Higher Education Forum. (1997). Spanning the chasm: Corporate and academic cooperation to improve workforce preparation. Retrieved from:

http://www.bhef.com/publications/documents/spanning chasm taskforce.pdf

Carter, D.N. (2006). Factors related to the developmental experiences of youth serving as Louisiana 4-H camp counselors. Unpublished doctoral dissertation, Louisiana State University, Baton Rouge. Retrieved from: http://etd.Isu.edu/docs/available/etd-11132006-104057

Casner-Lotto, J. (2006). Are they really ready to work? Employers' perspectives on the basic knowledge and applied skills of new entrants to the $21^{\text {st }}$ century U.S. workforce. Retrieved from the Conference Board Web site: http://www.conference-board.org/pdf free/BED-06Workforce.pdf

Cochran, G., Catchpole, K., Arnett, N., \& Ferrari, T.M. (2010). Extension's role in preparing youth for the workforce: A challenge to Extension professionals. Journal of Extension, 48(4), Article 4COM1. Retrieved from: http://www.joe.org/joe/2010august/comm1.php

Cochran, G., \& Ferrari, T.M. (2009). Preparing youth for the 21st century knowledge economy: Youth programs and workforce preparation. Afterschool Matters, 8, 11-25. Retrieved from: http://www.robertbownefoundation.org/pdf files/2009 asm spring.pdf

Cochran, G., \& Lekies, K. (2008). Skills for success in the knowledge economy. Retrieved from the Ohio State University Extension, 4-H Youth Development Web site:

http://www.ohio4h.org/workforceprep/documents/SkillsforSuccess-ActionBriefMay2008.pdf

Digby, J.K., \& Ferrari, T.M. (2007). Camp counseling and the development and transfer of workforce skills: The perspective of Ohio 4-H camp counselor alumni. Journal of Youth Development, 2(2), Article 0702FA007. Retrieved from the National Association of Extension 4-H Agents Web site: http://data.memberclicks.com/site/nae4a/JYD 070202final.pdf

Duda, S.L. (2009). Leadership and group facilitation skills in Florida 4-H camp counselors. Unpublished master's thesis, University of Florida, Gainesville.

Eccles, J., \& Gootman, J.A. (2002 Eds.). Community programs to promote youth development. Washington, DC: National Academy Press.

Ferrari, T.M., Arnett, N., \& Bateson, L. (2010, October). Work-based learning goes to camp: Results of a pilot study in Ohio. Research \& Evaluation Seminar presented at the National Association of Extension 4-H Agents annual conference, Phoenix, AZ. 
Ferrari, T.M., Arnett, N., \& Cochran, G. (2008). Preparing teens for success: Building 21st century skills through a 4-H work-based learning program. Journal of Youth Development, 3(1), Article 0803FA001. Retrieved from the National Association of Extension 4-H Agents Web site: http://data.m emberclicks.com/site/nae4a/JYD 080301final.pdf

Ferrari, T.M., \& McNeely, N.N. (2007). Positive youth development: What's camp counseling got to do with it? Findings from a study of Ohio 4-H camp counselors. Journal of Extension, 45(2), Article 2RIB7. Retrieved from: http://www.joe.org/joe/2007april/rb7.php

Forsythe, K., Matysik, R., \& Nelson, K. (2004). Impact of the 4-H camp counseling experience. Madison: University of Wisconsin-Extension, Department of Youth Development. Retrieved from: http://4h.uwex.edu/evaluation/documents/ImpactCampCounselor.pdf

Garst, B.A. (2010). From what to how: Targeting specific factors that influence outcomes. Journal of Extension, 48(6), Article 6COM1. Available at:

http://www.joe.org/joe/2010december/comm1.php

Garst, B.A., Franz, N.K., Baughman, S., Smith, C., \& Peters, B. (2009). "Growing without Limitations:" Transformation among young adult camp staff. Journal of Youth Development, 4(1), Article 090401FA002. Retrieved from the National Association of Extension 4-H Agents Web site: http://data.memberclicks.com/site/nae4a/JYD 090401final.pdf

Garst, B., \& Johnson, J. (2005). Adolescent leadership skill development through residential 4-H camp counseling. Journal of Extension, 43(5), Article 5RIB5. Retrieved from:

http://www.joe.org/joe/2005october/rb5.php

Greenberger, E., Steinberg, L.D., \& Ruggerio, M. (1982). A job is a job is a job...or is it? Work and Occupations, $9(1), 79-96$.

Grossman, J.B., \& Bulle, M. (2006). Review of what youth programs do to increase the connectedness of youth with adults. Journal of Adolescent Health, 39, 788-799.

Hamilton, M.A., \& Hamilton, S.F. (2004). Designing work and service for learning. In S.F. Hamilton \& M.A. Hamilton (Eds.), The youth development handbook: Coming of age in American communities (pp. 147-169). Thousand Oaks, CA: Sage.

Jones, J.N., \& Deutsch, N.L. (2010). Relational strategies in after-school settings: How staffyouth relationships support positive youth development. Youth and Society. doi: $10.1177 / 0044118 X 10386077$.

Larson, R.W., \& Angus, R.M. (in press). Pursuing paradox: The role of adults in creating empowering settings for youth. In M. Aber, K. Maton, \& E. Seidman (Eds.), Empowering settings and voices for social change. New York: Oxford.

Larson, R., Hansen, D.M., \& Walker, K. (2005). Everybody's gotta give: Adolescents' development of initiative and teamwork within a youth program. In J. Mahoney, J. Eccles, \& R. Larson (Eds.), After-school activities: Organized activities as contexts of development (pp. 159183). Hillsdale, NJ: Lawrence Erlbaum. 
Larson, R.W., Rickman, A.N., Gibbons, C.N., \& Walker, K.C. (2009). Practitioner expertise: Creating quality within the daily tumble of events in youth programs. New Directions for Youth Development, 121, 71-88. doi: 10.1002/yd297

Lamm, A., \& Harder, A. (2009). 4-H going beyond life skill development. Journal of Extension, 4Л4), Article 4COM1. Retrieved from: http://www.joe.org/joe/2009august/comm1.php

Levy, F., \& Murnane, R.J. (2006). Why the changing American economy calls for twenty-first century learning: Answers to educators' questions. New Directions for Youth Development, 110, 53-62.

Lippman, L., Atienza, A., Rivers, A., \& Keith, J. (2008). A developmental perspective on college and workplace readiness. Retrieved from the Child Trends Web site: http://www.childtrends.org/Files//Child Trends-2008 0915 FR ReadinessReport.pdf

Marshall, J.P., Higginbotham, B.J., Harris, V.W., \& Lee, T.R. (2007). Assessing program outcomes: Rationale and benefits of posttest-then-retrospective-pretest designs. Journal of Youth Development, 2(1), Article 0701RS001. Retrieved from: http://web.memberclicks.com/mc/page.do?sitePageId=100185\&orgId=nae4a

Partnership for $21^{\text {st }}$ Century Skills. (2002). Learning for the $21^{\text {st }}$ century. Retrieved from: http://www.21stcenturyskills.org/images/stories/otherdocs /P21 Report.pdf

Rhodes, J. (2004). The critical ingredient: Caring youth-staff relationships in after-school settings. New Directions for Youth Development, 101,145-161.

Rockwell, S.K., \& Kohn, H. (1989). Post then pre evaluation. Journal of Extension, 272), Article 2FEA5. Retrieved from: http://www.joe.org/joe/1989summer/a5.php

Schwarz, E., \& Stolow, D. (2006). Twenty-first century learning in afterschool. New Directions for Youth Development, 110, 81-99.

Veum, J.R., \& Weiss, A.B. (1993). Education and the work histories of young adults. Monthly Labor Review, 116(4), 11-20.

Walker, J.A. (2006). Intentional youth programs: Taking theory to practice. New Directions for Youth Development, 112, 75-92.

Walker, J., Marczak, M., Blyth, D., \& Borden, L. (2005). Designing youth development programs: Toward a theory of developmental intentionality. In J.L. Mahoney, R.W. Larson, \& J.S. Eccles (Eds.), Organized activities as contexts of development: Extracurricular activities, after-school, and community programs (pp. 399-418). Mahwah, NJ: Lawrence Erlbaum Associates.

(C) Copyright of Journal of Youth Development $\sim$ Bridging Research and Practice. Content may not be copied or emailed to multiple sites or posted to a listserv without copyright holder's express written permission. However, users may print, download or email articles for individual use. 